\title{
SPONDYLITIS ANKYLOPOETICA
}

\section{Szántó Sándor dr.}

$D E O E C$, Belgyógyászati Intézet, Reumatológiai Tanszék, Debrecen

\begin{abstract}
A spondylitis ankylopoetica (SPA) kezelése régóta nagy kihívást jelent a reumatológusok és a velük együttmúködő, a betegek mindennapi gondjaival gyakrabban szembesüló háziorvosok számára. A hagyományos terápiás eljárások, a gyógytorna és a nemszteroid-gyulladáscsökkentő szerek mellett a biológiai kezelések (TNF- $\alpha$ gátlók) elterjedése korábban elképzelhetetlen módon csökkentette a SPA-s betegek fájdalmát, javította életminőségüket és munkaképességüket. A TNF blokkoló monoklonális antitestek nemcsak az ízületi tünetekre hatnak kedvezően, hanem a SPA-t kísérő társuló tünetekre, az uveitisre, a gyulladásos bélbetegségekre és az enthesitisre is.
\end{abstract}

B. S. 31 éves gondozott férfibetegünknél 15 éves korában jelentkezett elóször recidiváló jellegü, aszimmetrikus térd és bokaízületi gyulladás, amelyhez kb. egy év múlva az Achilles-ín tapadásánál mindkét oldalon fájdalmas duzzanat társult. Atmenetileg nemszteroid-gyulladáscsökkentő (NSAID) kezelésben részesült, amelyre izületi duzzanatai megszüntek, az Achilles-ín területi fájdalmak és ödémák mérséklödtek. 16-17 éves korában észlelte derék- és keresztcsont tájéki fájdalmát, ami éjszaka, különösen a hajnali órákban erôsödött, napközben, mozgás hatására mérséklődött. A deréktáji fájdalmak miatt NSAID-ot szedett, amely fájdalmát csökkentette. 19 éves korában a jobb oldali szem gyulladásának és fájdalmának okaként iridocyclitis igazolódott, emiatt hospitalizációja vált szükségessé szemészeti osztályon. Szemcsepp és subconjunctivalis injekció formájában lokális szteroid kezelést kapott, erre megszünt szemgyulladása, de késóbb kiújult és recidiváló jellegüvé vált. Ekkor merült fel elöször szeronegativ spondylarthritis lehetôsége, mivel a betegnek korábban prosztatagyulladása is volt, Reiter-kórnak véleményezték. HLA-B27 meghatározás történt, ami pozitív eredményt adott. A következó években derékfájása tartóssá vált, majd a gerinc háti szakaszán is fájdalmat érzett, utóbbihoz a mellkasban jelentkezö abroncsszerú érzés is társult, ami a mély légvételt nehezítette. 25 évesen, 2003-ban jelentkezett elsó alkalommal reumatológiai szakrendelésen. Ekkor a panaszok jellege, az ágyéki gerinc mozgásának Schober-jellel igazolt beszúkülése és a mellkas légzési kitérésének csökkenése alapján spondylitis ankylopoetica (SPA) fennállását valószínúsítette, ezért betekintó sacroiliacalis felvétel történt, ami a bal oldali rés gyakorlatilag teljesen csontos ankylosisát, jobb oldalon pedig részleges ankylosist igazolt. Ennek alapján bal oldali IV-es, jobb oldali III-as stádiumú sacroileitis fennállása volt véleményezhetô. A típusos panaszok, a gerinctünetek és a röntgennel igazolt sacroiliacalis izületi eltérések alapján a SPA a módosított New Yorki kritériumrendszer szerinti diagnózisa felállitható volt. 2003 és 2007 között többféle NSAIDot szedett tartósan, így diclofenacot, naproxent, nimesulidot, de emellett sem csökkentek panaszai jelentősen, gerincét egyre merevebbnek érezte, évente 1-2 alkalommal pedig szemgyulladásai is visszatértek. Mivel az alkalmazott ún. hagyományos kezelés ellenére is aktívnak volt tekinthetô betegsége, vagyis a vízuális analóg skálák használatán alapuló BASDAI (Bath Ankylosing Spondylitis Disease Activity Index) $4 \mathrm{~cm}$ felett volt (egyik alkalommal 6,70, majd kb. 1,5 hónappal késóbb 6,84) TNF$\alpha$-gátló adalimumab (Humira) adása mellett döntöttünk. A kezelés elkezdése elött a beteg tájékoztatását anamnézisfelvétel és fizikális vizsgálat követte. A szükséges és kötelezô szürôvizsgálat részeként a rutin laboratóriumi vizsgálatok (vérkép, májenzimek, vesefunkciós vizsgálatok és vizeletvizsgálat) 
mellett kettôs-szálú DNS és nukleáris antigének elleni autoantitest meghatározások történtek. A Mantoux-teszt, a mellkasröntgen és az ezek ismeretében elvégzett tüdőgyógyászati konzílium ugyancsak elvégzésre került az elöirt vizsgálatok részeként. Ekkor SPA-ban a TNF-gátló terápia még az Országos Egészségbiztositási Pénztárhoz beadott egyedi méltányossági kérelemmel volt lehetséges, amelynek kedvezố elbírálása után 2007 nyarán tudtuk az adalimumab kezelést elkezdeni. A beteg az elsó injekció beadását követôen már néhány nappal a fájdalom gyakorlatilag teljes megszünését tapasztalta, s ez a kedvezó hatás a késóbbiekben is fennmaradt. A kezelés hatékonyságát tükrözö BASDAI-érték a 12. héten már 1,02 volt, és a késöbbi kontrollok során mindvégig 1 alatt maradt. A jelenleg már 2,5 éve folytatott kezelés mellett nemcsak a fájdalom teljes megszünése, hanem a gerinc mozgásának javulása is sokkal jobb életminóséget biztosított számára. Életéhez hozzátartozik a rendszeres gerinctorna mellett a szabadidős sporttevékenységek végzése is. A Humira kezelés mellett a korábban észlelt Achilles-ín területi enthesitise is megszünt, és a szemészeti gyulladások sem újultak ki. 2008 decemberétól az egyedi méltányossági kérelem helyett lehetôvé vált a gyógyszer 100\%-os támogatással történó felírása is, ami jelentősen csökkentette az orvosi adminisztrációs terheket is.

A fent leírt történetnek a kedvező kifejlet ellenére számos tanulsága van. Mivel a SPA rendszerint fiatal felnôttkorban kezdődik, általában 15-40 éves életkor között, a betegek a deréktáji fájdalmat gyakran túlterhelésnek, sportsérülés következményének tarják, emiatt későn, sokszor csak a kezdeti tünetek után évekkel kerülnek orvoshoz. Esetünkben ez a késés kb. 9 év volt, mivel az alsó végtagi arthritisek már a betegség kezdeti tüneteinek tarthatók. A SPA diagnózisának felállításához a jelenleg érvényben levô New Yorki-kritériumtünetek alapján a hagyományos röntgenvizsgálattal igazolt sacroileitis szükséges, amely radiológiai elváltozás kialakulása is sokszor évekig tarthat. A korai kórismét elősegítheti a pozitív családi anamnézis (nemcsak SPA, hanem egyéb spondylarthritis pl. arthritis psoriatica), tartósan fennálló, gyulladásos deréktáji fájdalomra utaló panaszok (gyakori felébredés hajnalban derék- vagy fartájéki fájdalomra, amely NSAID szedésére csökken), az alsó végtagi aszimmetrikus oligoarthritisek, enthesitisek (inak csonton való tapadási helyén kialakuló gyulladása) vagy uveitis jelenléte, HLA-B27 pozitivitás és a sacroileitis
MRI-vizsgálattal való korai igazolása. Ezen jelek közül néhánynak a megléte esetén a korai kezelés rendszeres gerinctorna, NSAID-ok formájában elkezdhetô, és évente végzett röntgenvizsgálattal célzottan lehet figyelni a sacroileitis kialakulását, amely a TNF- $\alpha$-gátló kezelés egyik alapfeltétele. Betegünk esetében az extra-skeletalis tünetek közül korán kialakult az enthesitis és az uveitis, amely a gyulladásos deréktáji fájdalommal együtt koraibb diagnózist tett volna lehetôvé. Viszonylag gyakran találkozhatunk egyéb kísérố tünetekkel is, mint a gyulladásos bélbetegség, psoriasis, amely extraskeletalis manifesztációk a betegség bármely stádiumában kialakulhatnak, egymással kombinálódhatnak. Ezek a kísérố tünetek befolyásolhatják a betegség kezelését is. Súlyos gyulladásos bélbetegség társulása esetén NSAID adása ellenjavallt, mivel előidézheti a béltünetek fellobbanását. A TNF- $\alpha$-gátlók közül a monoklonális antitestek (adalimumab, infliximab) hatásosnak tekinthetố a gyulladásos bélbetegségekre és az uveitisre, a TNF-receptor fúziós protein (etanercept) hatása ezekre a tünetekre jóval kisebb. Betegünk esetén a gyógyszerválasztást befolyásoló fontos tényezó volt a súlyos extraskeletalis tünetek megléte, így kezelésében a TNF-gátló monoklonális antitestek jöttek szóba. Mivel a beteg a szubkután öninjekciózást részesítette előnyben az infúziós kezeléssel szemben, adalimumab adása mellett döntöttünk, amelyet kéthetente 40 mg-os dózisban alkalmaz. A TNF- $\alpha$-blokkolók lehetséges mellékhatásai közül bizonyos fertôzésekre való fokozott hajlam említendô elsóként, ezek közül is kiemelendô a tbc-s infekció. Megfelelő anamnézisfelvétellel, felvilágosítással, a kezelés megkezdése előtt elvégzett szúrôvizsgálattal azonban ez a veszély minimalizálható. A potenciális mellékhatások közé tartozik még a középsúlyos vagy súlyos szívelégtelenség romlása, de ez a veszély is kiküszöbölhető, ha kérdéses esetben rendszeres kardiológiai kontrollvizsgálatok történnek. Mivel a SPA-s kezelt betegeink rendszerint fiatal- vagy középkorúak, ez általában nem jelent reális veszélyt. Felmerült tartós kezelés során a daganatos betegségek gyakoriságának esetleges fokozódása is, szerencsére sok ezer beteget magában foglaló regiszterek révén sem lehetett ezt igazolni.

Az alapellátásban dolgozó szakemberek a betegség diagnózisának felvetésével, a beteg biológiai terápiás centrumba utalásával, a betegséggel és annak kezelésével kapcsolatos napi teendốk ellátásával járulhatnak hozzá, hogy SPA-s betegeik a legkorszerúbb ellátásban részesüljenek. 